\title{
El recorrido de la analogía metafísica del actor en la comprensión de Ortega de la vida como tarea
}

\section{The course of the metaphysical analogy of the actor in Ortega's view of life as a task}

\author{
ENRIQUE FERRARI NIETO \\ Departamento de Ciencias de la Educación \\ Universidad de Extremadura (España)
}

\section{RESUMEN}

La analogía de Ortega del actor arrojado a un escenario no supone, como se ha sugerido en distintos trabajos, la inclusión de su metafísica en el entorno del tópico que entiende el mundo como un teatro. La identificación del individuo con un actor que debe transformarse en el personaje que perfila su vocación implica una concepción de mi vida, entendida como creación propia, opuesta a la del theatrum mundi, donde al actor le es asignado un papel ya escrito que debe representar dócilmente. Con todo, su definición del actor como metáfora corporizada converge -o puede llegar a converger- con su noción metafísica del hombre como existencial metáfora. Aunque Ortega no es explícito en este punto.

PALABRAS CLAVE

«IDEA DEL TEATRO», THEATRUM MUNDI, VOCACIÓN, RES DRAMÁTICA, METÁFORA CORPORIZADA

\footnotetext{
(C) Contrastes. Revista Internacional de Filosofía, vol. XVIII (2013), pp. 319-337. ISSN: 1136-4076 Licenciatura de Filosofía, Universidad de Málaga, Facultad de Filosofía y Letras Campus de Teatinos, E-29071 Málaga (España)
} 


\begin{abstract}
Ortega's analogy of the actor who is thrown into a scenario does not imply the inclusion of his metaphysics in the literary topic that understands the world as a theatre. Ortega identifies the person as an actor who must become the character that his vocation writes. This implies a conception of «my life», understood as my creation, which is contrary to the Theatrum Mundi's, in which the actor is assigned a previously written role. However his definition of the actor as embodied metaphor could converge with its metaphysical notion of man as an existential metaphor. Ortega is not explicit on this point, though.
\end{abstract}

KEYWORDS

«THE IDEA OF THEATRE», THEATRUM MUNDI, VOCATION, RES DRAMATICA, EMBODIED METAPHOR

\title{
I. INTRODUCCIÓN
}

Estudios Recientes -los de Luis Miguel Pino Campos y Eve Giustiniani ${ }^{1}$ han revitalizado «Idea del teatro» con el análisis de las distintas ediciones del texto, tras el desprecio general anterior, de obra menor, ${ }^{2}$ que el propio Ortega alimentó. ${ }^{3}$ Con las variantes textuales de una y otra edición (que explica la carta, descubierta ahora, que Ortega escribió a Pedro Rocamora en agosto de 1946, impidiendo la publicación de su conferencia en el Ateneo en la Revista

1 De Luis Miguel Pino Campos: «En torno a "Idea del teatro" de José Ortega y Gasset: Aportaciones y nuevas consideraciones», Revista de filología de la Universidad de La Laguna 27 (2009) pp. 123-138. «Las ediciones de "Idea del teatro" de José Ortega y Gasset: algunas notas críticas», Revista de filología de la Universidad de La Laguna 24 (2006) pp. 203-214. Y: «Los orígenes del teatro y la filosofía en José Ortega y Gasset». En J. Lasaga et. al. (eds.), Ortega en pasado y en futuro. Medio siglo después. Madrid, 2007, Anexo II, 6. De Eve Giustiniani: «1946. Las conferencias de Lisboa y Madrid sobre "Idea del teatro"», Revista de estudios orteguianos 14-15 (2007) pp. 43-92.

2 Por ejemplo: G. Morán, El maestro en el erial. Ortega y Gasset y la cultura del franquismo. Barcelona: Tusquets, 1998, p. 149.

3 Dice en Madrid, para justificar su conferencia: «Es un tema por lo demás muy del sesgo acostumbrado en la mejor tradición de esta casa, que siempre procuró ocuparse de asuntos aparentemente superfluos» (IX, 882) [Las referencias a Ortega remiten a sus Obras completas publicadas en diez tomos por Taurus y la Fundación Ortega-Marañón entre 2004 y 2010. En números romanos el tomo y en arábigos la página]. 
Nacional de Educación), ${ }^{4}$ se han destacado las implicaciones políticas del texto añadido a la conferencia de Madrid, solo unas líneas al comienzo, como una respuesta al régimen de Franco, tan difícil todavía de medir. Para el profesor Pino, una alegoría, un modo indirecto, con el teatro de excusa, de plantear la realidad española sin ser censurado: ${ }^{5}$ «En España, como en el teatro -escribe-, se representaba una farsa: la vida española era una fantasmagoría, de tal forma que -cabría decir- todos los españoles eran unos "farsantes", pues tenían que realizar un papel que no era el suyo». ${ }^{6}$ Una tesis, ésta de la alegoría política, más sustanciosa que las referencias a su regreso a España de Zamora Bonilla, o de Lasaga, también recientes, o de Abellán. ${ }^{7}$ Pero que ni Pino Campos ni Giustiniani amarran bien a la filosofía de Ortega, al entramado metafísico que plantea para la vida, a su noción de drama, que Ortega no quiere como metáfora; forzando la comparación, suponiéndole lo que no llega a decir, aunque se quede tan cerca a veces, merodeando, pero prudente. Escribe el profesor Pino: «[Algunas expresiones] encajaban plenamente en la filosófica "Idea del teatro", de la vida como teatro o de la circunstancia en el marco metafórico del teatro que es la vida cotidiana». ${ }^{8} \mathrm{O}$, años más tarde, más sintético: «El teatro, en definitiva, era como la vida», ${ }^{9}$ con cursiva suya, sin señalar la referencia que toma de los textos de Ortega, como si reconociera que se aleja de su sentido exacto, que es él mismo el que estira la imagen orteguiana del actor arrojado a un escenario hasta convertir el mundo en un teatro. Y Eve Giustiniani, apoyándose en una cita que entiende mal: «Ortega utiliza a menudo, en sus escritos, la calderoniana

4 Cf. E. Giustiniani, «1946. Las conferencias de Lisboa y Madrid sobre "Idea del teatro"», op. cit., p. 62.

5 Contrario a la tesis del «imperativo de continuidad» de Giustiniani: «El tema de la conferencia -señala- debió de elegirlo él mismo; no solo aprovechó el trabajo realizado para la conferencia de Lisboa, sino que el tema del teatro le permitía hablar públicamente sin rozar-por lo menos declaradamente- asuntos sociales o políticos. En suma, era una forma "inofensiva" de marcar su regreso a España, y una ocasión para probar el ambiente cultural madrileño y la receptividad de las nuevas generaciones hacia él» (2007, p. 62).

6 L.M. Pino Campos, «En torno a "Idea del teatro" de José Ortega y Gasset: Aportaciones y nuevas consideraciones», op. cit., p. 126.

7 J. Lasaga Medina, José Ortega y Gasset (1883-1955). Vida y filosofía. Madrid: Biblioteca Nueva, 2003, pp. 161-162; J. Zamora Bonilla, Ortega y Gasset. Barcelona: Plaza y Janés, 2002, pp. 461-462; J.L. Abellán, Ortega y Gasset y los orígenes de la transición democrática. Madrid: Espasa-Calpe, 2000, pp. 149-150.

8 L.M. Pino Campos, «Las ediciones de "Idea del teatro" de José Ortega y Gasset: algunas notas críticas», op. cit., p. 206.

9 L.M. Pino Campos, «En torno a "Idea del teatro" de José Ortega y Gasset: Aportaciones y nuevas consideraciones», op. cit., p. 127. 
metáfora del "gran teatro del mundo", como en ¿Qué es filosofía? (Oc83, VII, $366 s s.) \gg .{ }^{10}$

Ortega no alude a la imagen del actor o del personaje para explicar su noción de la vida como tarea en «Idea del teatro». En trabajos anteriores sí. Pero se cuida mucho de no decir más que lo que quiere decir, manteniendo a raya las asociaciones inevitables entre lo escrito y lo sugerido, por su cercanía -en un primer vistazo- con otras propuestas de mucho peso, como esta de la representación del mundo como un teatro, el theatrum mundi, uno de los grandes tópicos literarios.

En «Idea del teatro» se abre camino con una dialéctica alegre, sin contenciones, poco atento con el tema de partida, que se quita de encima en seguida. Apunta el objeto de la conferencia, que él no ha decidido, pero se escabulle rápido para dar con el punto que considera más valioso: el engarce que les encuentra a la estética y la metafísica en su filosofía, el arte como mecanismo para evadirse el hombre de su propia vida, que ha recorrido antes, en otros trabajos, sobre todo con la novela. Señala al principio que el tema de la charla es una definición del teatro, pero echa mano de dos excusas para alejarse de su objetivo inicial: primero, la decadencia en que se encuentra entonces el teatro, como si estuviera enfermo, dice, que lo obligaría, para dar con buenos ejemplos a acudir al pasado; pero la propia dinámica del congreso en Lisboa, con otras conferencias específicas, lo exonera a él -la segunda excusa- de tratar los casos particulares. El encargo es una valoración como género, pero como género literario Ortega lo descarta de inmediato. Lo había hecho mucho antes, en 1921, en «Elogio del "Murciélago"». ${ }^{11}$ Lo que le interesa es enfocar el teatro como un espacio, como un edificio, para encauzar su exposición con el binomio arte y realidad, o irrealidad y realidad, que luego traslada, en paralelo, a los individuos: los actores y los espectadores. ${ }^{12}$

Aunque quepan otras lecturas, el texto es una vuelta a su propuesta estética, con la que había asimilado el arte (también el arte nuevo) a su filosofía como

10 E. Giustiniani, «1946. Las conferencias de Lisboa y Madrid sobre "Idea del teatro"», op. cit., p. 51. La referencia de Ortega al teatro en ¿Qué es filosofía? no es una imagen o una metáfora de la vida, como piensa Giustiniani: alude a la realidad que le es más cercana en ese momento, al teatro donde dicta esas conferencias: la séptima en el teatro Infanta Beatriz.

11 Con motivo de la llegada a Madrid de un espectáculo de artistas rusos, que combina el baile, canciones, coros, cuadros plásticos y bufonadas, muy alejado del teatro tradicional, escribe Ortega: «Es preciso que en la obra teatral sea lo necesario y sustantivo el teatro; por lo tanto, que la obra escénica consista primordialmente en un suceso plástico y sonoro, no en un texto literario; que sea un hecho insustituible ejecutado en la escena» (II, 446).

$12 \mathrm{El}$ actor, dice, es el hiperactivo, que está en escena para ser visto por un público hiperpasivo (IX, 834). Su trabajo es hacer farsa. Y el del público asimilar esa farsa como tal: salir de su vida real para entrar en un mundo fantasmagórico (IX, 844). 
farsa y, por tanto, como evasión, legitimado como el descanso posible que le permite a cada uno el constante esfuerzo que es vivir. Con esa prolongación en terreno metafísico que, en «Idea del teatro», concreta casi al final: «Todo el resto de nuestra vida es lo más contrario a la farsa que se puede imaginar -es constante, abrumadora "seriedad". [...] Vivir es hallarse de pronto teniendo que ser, que existir en un orbe imprevisto que es el mundo. [...] Vida es tener que ser, queramos o no, en vista de unas circunstancias determinadas. [...] Nos ha sido dada pero no nos ha sido dada hecha, sino que tenemos que hacerla» (IX, 845). La versión corta de su exposición en ¿Qué es filosofía?, la misma propuesta de comprender la vida como una tarea. Pero que en su libro de 1929 apuntala con un símil, para explicarse mejor: Como un actor, escribe, que se despierta de pronto en un escenario y debe improvisar delante del público (VIII, 356). Una figura que Ortega repite luego en otros trabajos, que analiza incluso en su dialéctica con el personaje que cada uno representa, para explicar qué entiende por vocación, pero que en «Idea del teatro» prefiere omitir, aunque la referencia a su comprensión de la vida es la misma. Define al actor como la metáfora corporizada, como un elemento más del teatro, pero evita usarlo como imagen de su metafísica, que él mismo llama dramática.

Es siempre cauto, muy comedido, al hacer confluir vida y teatro. Su intención no es continuar, ni tampoco darle la vuelta, a la tradición filosófica que comprende el mundo como un teatro. A pesar de manejarse con una ontología dramática, del hombre como res dramática, $\mathrm{y}$, al tiempo, con un actor hecho metáfora, capaz de transmitir, por tanto, el carácter ejecutivo de la realidad. A pesar, también, de las implicaciones que parece sugerir el mecanismo de la metáfora (del actor), como aniquilación de dos realidades para la creación de esa nueva irrealidad en el arte, para explicar la unión del yo idealista y la circunstancia -mejor que los Dii consentes- en ese nuevo elemento filosófico de partida que es mi vida. A pesar, por último, de esa capacidad creativa que él destaca del actor, que señala bien el punto de partida de su filosofía, radicalmente existencial, al acabar con el rol del autor (del Autor), tan importante (porque asigna él los papeles, por tanto las vidas) en cualquiera de las aproximaciones al tópico del theatrum mundi. ${ }^{13}$

La vida es drama: es el eje de la filosofía de Ortega, de su propuesta para un tiempo nuevo (para una sensibilidad nueva) que hace de la vida la realidad radical que la fenomenología (al principio, al menos; en la denuncia de Ortega, al menos) ${ }^{14}$ había buscado lejos, en la conciencia, a una distancia prudencial del

13 En las diferentes versiones del tópico el actor no es más que un tipo pasivo, y sumiso, que solo se enguanta en el papel que le ha tocado.

14 Cf. J. San Martín, La fenomenología de Husserl como utopía de la razón. Barcelona: Anthropos, 1987, pp. 121-122. 
ajetreo de cualquier existencia. ${ }^{15}$ La vida-escribe convencido-es un quehacer, una tarea: para nada el sujeto inamovible, de armazón fijo, separado y enfrentado al mundo, sino el yo y su circunstancia, res dramatica, no res cogitans; que funciona de matriz para las demás ámbitos de su filosofía, que quedan amarrados a este punto de partida. Entre ellos el estético, con su polémica deshumanización del arte, que significa, en último término, un rebajamiento de categoría para este, después de haber sido encumbrado por los románticos, incluso por encima de la propia vida. Porque el arte, como cualquier otra manifestación cultural, dice Ortega, no puede pretender competir con la vida misma. Es otra cosa: irrealidad, dice, sin detenerse demasiado en explicar qué entiende por irreal cuando escribe de arte, cuál es su origen y qué lo distingue de lo real. ${ }^{16}$ Pero que impone, para que la percepción sea propiamente estética, que haya un marco, o, con otra imagen, esta sacada del teatro, un telón, que fije bien esta separación tajante con la realidad, con la vida cotidiana del espectador o del lector: «Dilata sus anchas fauces como un paréntesis dispuesto para contener otra cosa distinta de las que hay en la sala», escribe (II, 436). Una degradación que no es más que un reajuste de todas las actividades en un plano inferior al de la propia vida, única realidad radical; que no afecta a la valoración propiamente estética, intrínseca del arte, a la que Ortega le dedica un espacio importante en su obra, sobre todo a la novela, y también a los años convulsos de las vanguardias, en torno a 1925, y a algunas figuras destacadas, como Velázquez o Goya. No al teatro, que no le interesa, y del que escribe poco, y por encargo. Pero esta degradación (o solo reformulación) del arte como irrealidad, como otra cosa distinta que la realidad, rebajado su estatus, le permite conectarlo con la metafísica, con su función propia en un planteamiento puramente ontológico. Como el engranaje (o el dispositivo que pone en marcha ese engranaje) capaz de rebajar, por un momento, la tensión que supone la tarea incesante que es vivir. Con una formulación mejor anclada, más ajustada, ${ }^{17}$ que el recurso de la mímesis, de la representación en el escenario de una acción elevada, como

15 Escribe en ¿Qué es filosofía?: «La conciencia no es reclusión sino al contrario es esa extrañísima realidad primaria, supuesto de toda otra que consiste en que alguien, yo, soy yo precisamente cuando me doy cuenta de cosas, de mundo» (VIII, 344).

16 Escribe en 1912, en «Nuevo libro de Azorín»: «La tabla, el lienzo poseen solas dos dimensiones. A esta representación superficial son sometidos los cuerpos. Y ¿qué acontece con la tercera dimensión, con la profundidad? Ahí está, en el cuadro; pero reabsorbida por las otras dos; está y no está. Y todas las cosas dentro de ese irónico espacio comienzan una existencia virtual, viven sin vivir en sí y mueren porque no mueren, gozando de una vitalidad esencial y simbólica que les ha labrado el ingenioso triunfo del artista sobre la tercera dimensión» (I, 536).

17 Más manejable también con otras artes, y con estilos menos figurativos. 
escribió Aristóteles: ese isomorfismo entre arte (narrativo) y vida, tan intuitivo, con un alcance que es también metafísico. ${ }^{18}$

Pero Ortega, insisto, se cuida mucho de entrecruzar (o superponer o continuar) uno y otro recorrido. Aunque en ambos confluyan vida y teatro. En uno de ellos el teatro es la evasión, o el mecanismo para esa evasión; un apéndice de un camino mucho mayor, porque el hombre necesita escapar de su propia vida de vez en cuando, salir fuera del mundo, ensimismándose, concentrado por ejemplo en una representación teatral, en una farsa, una fantasmagoría: el punto en que acaba su «Idea del teatro». Para el otro recorrido, el teatro, el drama, no es una imagen o una metáfora. Es la estructura que quiere Ortega para comprender la vida, para explicarla lejos de la noción eleática del ser, que lo concebía como algo prefigurado. Para hacer de la «persona», que se entendía antes como una sustancia, un «personaje»: ${ }^{19}$ un proyecto, una creación propia que tiene que sugerirle a cada uno su vocación. Pero sin echarse encima los demás elementos del teatro, sin tener que buscarles su hueco, esa coherencia mínima en la analogía que sugiere, con el actor y su personaje, su comprensión de la vida.

\section{IDEA DEL TEATRO}

Ortega escribe disperso, y apresurado,${ }^{20}$ con textos de pocas páginas que son como capas que añade al núcleo de su propuesta filosófica, que así va ocupando más terreno, más volumen, con las matizaciones y digresiones, y los casos concretos y los temas nuevos. Sin afianzarlo con unos pocos tratados más compactos, más prietos. Pero sin desplazar tampoco su apoyo, ese lugar entrevisto ya en 1914, con sus programáticas Meditaciones del Quijote, con su «Yo soy yo y mi circunstancia» (I, 757), que irá engordando luego al paso de la filosofía europea del siglo XX (Dilthey, Heidegger...), pero siempre desde su perspectiva española. Son artículos en la prensa o apuntes o charlas en los que el tema que se le pide (los toros, la caza, el amor, sobre biblioteconomía, Goethe...) queda amarrado a su razón vital. Porque lo aborda como si fuera uno de los dos cabos, el que cambia con cada tema, con cada propuesta que se le hace o que él

18 El propio Ortega parece insinuar también este isomorfismo, muy pronto, en sus Meditaciones del Quijote: «El actor en el drama, podría decirse paradójicamente, representa un papel que es, a su vez, -escribe entonces- la representación de un papel bien que en serio esta última» (I, 819). Aunque aquí la analogía -que no se refiere al hombre en general, sino a un tipo concreto de hombre, el héroe- es solo una precipitación, una idea más de otros que de él mismo, tomada sin más, inevitablemente ambigua (porque en el primer caso -con el actor- enfoca la cuestión en su interpretación, en la actuación; en el segundo -con el héroe- en su capacidad creativa, para escribirse él mismo su papel, su vida); que no va a repetir.

19 Cf. J. Lasaga Medina, Figuras de la vida buena. Madrid: Enigma Editores, 2006, pp. 215-216.

20 Para Fernando Vela: «[Su filosofía está] desparramada nerviosamente» (V, 109). 
asume, porque el otro es firme, siempre el mismo punto de partida, y le basta con unirlos, con ocupar el espacio que queda entre ellos. Y porque, al tiempo, cumple con ese código deontológico que es la continuación de su sentencia de las Meditaciones: «Y si no la salvo a ella [a la circunstancia] no me salvo yo». ${ }^{21}$ Aunque algunos de esos temas le sean tan lejanos. Como el teatro, más que la caza o los toros. Por el objeto mismo de la reflexión. Pero, también, por la coyuntura de sus conferencias -primero en Lisboa y luego, repetida, en el Ateneo de Madrid-en 1946, un momento delicado para Ortega y también para España, con el régimen de Franco afianzado cuando él decide regresar tras diez años de exilio, con una maniobra de equidistancias arriesgada. ${ }^{22}$

Algo había dicho ya del teatro antes. En 1939, en Buenos Aires: «Yo no voy casi nunca al teatro» (V, 447). Porque, dice (había dicho antes, en 1921), prefiere leerlo en un libro que verlo representado: «Eso que añade el actor me parece inesencial. Para una sensibilidad educada es, decididamente, un estorbo» (II, 445). ${ }^{23}$ Aunque lo cierto es que tampoco lo lee, ni escribe de él más que alguna nota suelta, cuando hace de crítico y rastrea entre lo nuevo. ${ }^{24}$ Menos que de poesía, que tampoco lee a menudo, pero de la que echa mano en su estética, en su deshumanización del arte, para explicar sus mecanismos. Pero pasados los años, después de veinte en que apenas habla de arte, después de esos intensos años en torno a 1925 en que se propone asimilar el arte nuevo y darle un sentido desde la razón vital, vuelve al teatro con una conferencia en Lisboa, el 13 de abril de 1946, que le encarga el periódico $O$ seculo para abrir un ciclo dedicado a la historia del teatro. Aunque le apetece poco: lo considera un asunto aparentemente superfluo, como reconoce luego en Madrid, y poco filosófico, menos interesante, dice, que el propio nombre del periódico. Al comienzo remolonea, como otras tantas veces, apuntando otras posibilidades, para destensar las expectativas por el tema, del que sabe poco, en un auditorio -el de Lisboa- de expertos. Se centra en el método, en el camino de la reflexión mejor que en los resultados. Lo avisa: «Aprovechando este tema, que no parece filosófico, quiero dar ejemplo del más rigoroso método dialéctico -y a la vez fenomenológico» (IX, 833). Deja a un lado el teatro de su tiempo, que dice que está en ruina, como casi todo, aunque el diagnóstico no es exhaustivo, y se atreve con un planteamiento puramente

21 Cf. A. Rodríguez Huéscar, Semblanza de Ortega. Barcelona: Anthropos, 1994, p. 255 .

22 Cf.A. Marco Ferrusola, «Una hermenéutica del silencio en Ortega», Revista de Estudios Orteguianos 4 (2002) pp. 89-110.

23 También: «Hoy, un hombre capaz de percibir las calidades superiores de la obra dramática, goza de esta íntegramente sin necesidad de verla representada» (II, 445-446).

24 Giustiniani defiende la tesis contraria: «A Ortega le interesa el tema del teatro desde hacía muchos años, a pesar de haberle dedicado pocos ensayos.» (2007, p. 50). 
teórico del teatro como género ${ }^{25}$ que le funciona, primero, de molde para su propuesta estética, común a todas las artes, con su división entre lo real y lo irreal, en el que encaja cada elemento, y luego, en un plano más ambicioso, en el engarce con la metafísica, como el resorte del descanso en su comprensión de la vida como tarea, como un quehacer ininterrumpido.

Con el teatro retoma -con una exposición más ordenada- su comprensión del arte como irrealidad, como otra cosa que la realidad. Avanza poco a poco en la charla, demorándose en cada paso, como si se imaginara a sí mismo llevando de la mano a un público que le sigue a ciegas o por primera vez, desacostumbrado ya a sus discursos. ${ }^{26}$ Sabe que estas conferencias son su reaparición después de un tiempo difícil, en el que se ha impuesto a sí mismo el silencio, y también el trabajo concienzudo de darle una forma más sólida, más compacta, a su filosofía, que ahora expone desde ese cabo que en esta ocasión es el teatro. Su reflexión del arte aquí, con el teatro de paradigma, es una vuelta a exposiciones anteriores con la poesía o la pintura, pero que le conviene recordar, después de tantos años de haberlo arrinconado. El arte, había escrito mucho antes, es irreal por dos motivos: primero porque es algo distinto a lo real, pero también porque lleva dentro de sí la trituración de la realidad. Lo entiende como plenamente autónomo, en clave ontológica: una cosa es el arte y otra cosa es la vida, y no deben mezclarse, dice, porque percibirlas del mismo modo es bizquear. El arte es un continente separado de la realidad, una abertura de irrealidad. Uno y otro, arte y realidad, son los dos espacios que crean los bastidores del retablo del maese Pedro del Quijote: hacia dentro, escribe, se desarrolla el orbe fantástico; hacia fuera, el aposento donde se reúnen unos cuantos hombres. Con la referencia del propio edificio que es el teatro, con el dibujo del teatro Doña María de Lisboa, la sala de butacas y la escena, el espacio del público y el de los actores, separados por un telón que delimita la realidad y la irrealidad. Una imagen muy intuitiva, como la del marco de un cuadro, que separa la pintura de la pared con ese espacio imparcial, esa tierra de nadie que sirve de transición, en el teatro con ese telón, dice Ortega, que libera al espectador de su horizonte real y lo traslada a ese nuevo horizonte de la ficción en el que el actor representa una farsa para el público, que le sirve para salir de su vida real y adentrarse en ese otro mundo (IX, 844-845). Como si la propia ficción -aunque él no es tan explícito- llevara al espectador a ensimismarse y por tanto, de algún modo, a

25 En «Elogio del "Murciélago"», mucho antes, ya había abordado la cuestión, con su apuesta por un nuevo tipo de teatro. Escribe entonces: «Lo insuficiente del viejo arte teatral es el género mismo, y lo acertado en estos ensayos rusos es su carácter genérico» (II, 441); o: «El nuevo arte de teatro es lo que queda del viejo, cuando se elimina de él todo lo que no es teatro; por tanto, todo lo que le sobra» (II, 444).

26 Comienza en el Ateneo: «Toda una generación de muchachos ni me ha visto ni me ha oído y este encuentro con ella es para mí tan problemático [...]» (IX, 880). 
evadirse de su realidad cotidiana, a olvidarla o a dejarla en suspenso, sin ninguna comunicación con su entorno. A desconectar, con esta otra imagen que tenemos en castellano. A convertirlo en sonámbulo, dice él. El engarce exacto entre su estética y su metafísica: el arte, intrascendente, irreal, porque es autónomo (otro mundo), le abre al hombre la única posibilidad que tiene de abandonar por un momento la tarea que es su propia vida, el quehacer constante que le supone vivir. No hay modo de descansar saliendo uno fuera de sí mismo, dejando de vivir (el trabajo que supone vivir), por un momento, porque la vida es una tarea que no se interrumpe, hasta la interrupción definitiva que es la muerte. Pero como solución parcial a Ortega le vale la operación inversa, ensimismándose el individuo, concentrándose en sí mismo a través de la ficción, como si esta activara el mecanismo, para dejar en suspenso su reacción ante la circunstancia que lo comprende; para evadirse, dice. La materialización más viable de la respuesta bravucona de Baudelaire, que él recupera, cuando le preguntan dónde querría estar: « $i \mathrm{Ah}$, en cualquier parte! ¡En cualquier parte con tal que sea fuera del mundo!» (IX, 846).

\section{El hombre de Ortega, nOVELISTA Y DRAMATURGO}

En Ortega la vida no tiene un sentido biológico, sino biográfico: la lucha del hombre con su entorno, un dinamismo dramático entre yo y el mundo; no dejarse ser, como cualquier otro animal (IX, 443). La vida es drama, explica, porque consiste en tener cada uno que ir haciéndose a sí mismo, en perpetua tensión. No es una metáfora. Drama, de drao, significa actuar, ejecutar. Escribe en En torno a Galileo: «El drama no es una cosa que está ahí [...] sino que el drama pasa, acontece, se entiende, es un pasarle algo a alguien, es lo que acontece al protagonista mientras le acontece» (VI, 387). Es faena poética, ${ }^{27}$ un hacer nuevo que hay que crear. No el alma y el cuerpo, que son cosas, sino un quehacer, una tarea, un drama: res dramática. Como ya intuyó Montaigne, que vio que el hombre era una realidad ondulante y diversa, sustancial cambio. O Goethe, el primero, dice, que tuvo claro que la vida tenía valor por sí misma, con ese «Dios te da la nuez, pero sin cascar» suyo, que Ortega arropa en su filosofía (una razón, después de todo, narrativa): «Nuestra vida, la de cada uno de nosotros -escribe-, nos ha sido dada, pero no nos es dada hecha, sino que es una tarea, es algo que tenemos que hacer, que hacernos» (VI, 552).

Se propone devolver el sujeto trascendental al mundo: pensarlo junto a su circunstancia, con su entorno como constitutivo de él para escapar de las apreturas de un idealismo al que, por entonces, se le abren varios frentes, con la fenomenología de Husserl misma, aunque Ortega no quiso verlo, o con el

27 En síntesis: Cf. J. Conill, «Razón experimental y ética metafísica en Ortega y Gasset», Revista de estudios orteguianos 7 (2003) pp. 95-117. 
desarrollo posterior de Heidegger y, después, del existencialismo francés, con la vida como angustia. Cerca de Ortega, pero con un gesto más trágico, más melodramático, como dice él mismo: porque la vida, para sentirla como angustia hay que sentirla primero como empresa; para sentir la angustia es preciso seguir en la vida; fuera de la vida no hay posibilidad de angustia. Ésta queda comprendida en aquella. Seguir en la vida, escribe, es aceptar libérrimamente la angustiosa tarea: un esfuerzo deportivo (IX, 541). Otra perspectiva, otro talante, que centra la cuestión en la comprensión -necesariamente previa- de la vida como creación. Como si fuera una obra de arte. ${ }^{28}$ Lo mejor -afirma en Meditación de nuestro tiempo- es aceptarla alegremente, reconocer que con ella nos es dado el tema para una creación (VIII, 50). Pero Ortega, para darle cuerpo a su propuesta, a su enfrentamiento concreto con el idealismo, necesita un código nuevo, tomar los conceptos de realidad y de ser tradicionales y amoldarlos poco a poco, irlos convirtiendo en otros, también nuevos, capaces de hacer suyo el dinamismo que la vida le imprime a todo..$^{29}$

Con dos imágenes, muy intuitivas, hace de la vida un género literario, la invención del personaje que cada cual tiene que ser: «Existir se convierte para el hombre en una faena poética, de dramaturgo o novelista: inventar a su existencia un argumento, darle una figura que la haga, en alguna manera, sugestiva y apetecible», escribe en «A Veinte años de caza mayor del conde de Yebes» (VI, 272).

A la del novelista volverá más veces. Como el autor que escribe el propio argumento de su vida, que lo va escribiendo, porque no está escrito previamente en un ser fijo e invariable, ${ }^{30}$ a un tiempo el autor y el personaje, con dos funciones que no se distinguen, que se solapan en un mismo sujeto que es (a la fuerza, lo quiera o no) autónomo, libre, porque no tiene una identidad constitutiva, no puede instalarse para siempre, como pretendían otras ontologías, en ningún ser determinado; porque tiene que inventarse una figura de vida, el personaje que va a ser. ${ }^{31}$ Porque es gerundio, no participio, un faciendum, dice,

28 P. Cerezo Galán, La voluntad de aventura. Barcelona: Ariel, 1984, p. 150.

29 Escribe en «¿Qué es filosofía?»: «Hemos hallado una realidad radical nueva-por tanto, algo radicalmente distinto de lo conocido en filosofía-, por tanto, algo para lo cual los conceptos de realidad y de ser tradicionales no sirven. $\mathrm{Si}$, no obstante, los usamos es porque antes de descubrirlo y al descubrirlo no tenemos otros. Para formarnos un concepto nuevo necesitamos antes tener y ver algo novísimo» (VIII, 347.

30 Cerca del homo viator del cristianismo, como ha visto A. Regalado en El laberinto de la razón: Ortega y Heidegger. Madrid, Alianza, 1990, p. 203.

31 Escribe Ortega: «[Las posibilidades del ser] tengo que inventármelas [...]. Invento proyectos de hacer y de ser en vista de las circunstancias. Eso es lo único que encuentro y que me es dado: la circunstancia. Se olvida demasiado que el hombre es imposible sin imaginación, sin la capacidad de inventarse una figura de vida, de "idear" el personaje que va a ser. El hombre 
no un factum. ${ }^{32}$ Cualquier otro punto de partida, escribe Marías, su discípulo, llega tarde, no es radical, si no se asienta en la concepción de $m i$ vida, como la organización real de la realidad, de la realidad como escenario de $m i$ vida, ${ }^{33}$ que consiste en hacerse uno a sí mismo, proyectivamente, en la expectativa, eligiendo quién ser (la vocación de Ortega), porque uno no es idéntico siempre (no tiene una identidad), pero sí es siempre el mismo. Es futurizo, argumental, en una realidad inconclusa: «Vivir -sigue Marías- es proyectar, imaginar, anticipar, es seguir proyectando, imaginando, anticipando, soy inexorablemente futurizo, orientado al futuro, remitido a él» ${ }^{34}$ Nuestra vida es toparse con el futuro -escribe Ortega-, es una actividad que se ejecuta hacia adelante (VIII, 358). Un hallazgo en el que a la filosofía se le adelantó la literatura, con mejores instrumentos para entender la persona como un argumento, ${ }^{35}$ por el propio mecanismo de la narración, del relato, que es movimiento, frente al objeto con el que ha creído enfrentarse la filosofía; y también por las analogías, que aciertan con nuevas miradas: la vida como un río, o una fuente, o un viaje, por ejemplo. Escribe Piglia: «El arte de narrar es un arte de la duplicación; es el arte de presentir lo inesperado; de saber esperar lo que viene, nítido, invisible, como la silueta de una mariposa contra la tela vacía». ${ }^{36}$ En la expectativa, había dicho Marías. Animal hipotético. Peregrino del ser, para Ortega (VI, 72). Muy cerca también de los apuntes de antropología de Steiner, que reconocen en el hombre la capacidad exclusiva de pensar lo que no ha pasado aún pero puede llegar a pasar o podría haber pasado, con los tiempos y modos verbales que lo indican; el futuro, el condicional o el subjuntivo en castellano: «Solo el hombre posee el modo de alterar su mundo por medio de cláusulas incondicionales», escribe en sus Gramáticas de la creación. ${ }^{37}$

La imagen del dramaturgo, en cambio, Ortega la deja a un lado; aunque es más visual que la del novelista, más fácil de comprender, porque parte del recorrido está ya hecho, con el teatro como lugar dramático, como metáfora de la existencia, a la que acude, de hecho, una vez (y repite en otras dos o tres ocasiones), para explicar la condición del hombre de náufrago en su vida, en su existencia, pero sin llegar a empalmar el resto de conexiones de la imagen con

es novelista de sí mismo, original o plagiario».

32 Hace del Amadís de Gaula un precedente. Escribe: «Dice de sí mismo, de su vida, de lo que ha pasado y hecho: que es su hacienda [...]. La hacienda es el faciendum, es el gerundio, lo que hay que hacer [...]» (IX, 539).

33 J. Marías, Antropología metafísica. Madrid: Revista de Occidente, 1970, p. 66.

34 J. Marías, Antropología metafísica. op. cit., p. 299.

35 Aunque su aproximación, dice Marías, no ha sido suficiente, poco más que la intuición. Cf. J. Marías, Persona. Madrid: Alianza, 1997, p. 82.

36 R. Piglia, Formas breves. Barcelona: Anagrama, 2000, p. 137.

37 G. Steiner, Gramáticas de la creación. Madrid: Siruela, 2001,p. 16. 
su filosofía, sin demasiadas pretensiones, dejando fuera los puntos problemáticos. Escribe en «Meditación de nuestro tiempo», en 1928: «Nuestra vida empieza por ser la perpetua sorpresa de existir sin nuestra anuencia previa, náufragos en un orbe impremeditado. No nos hemos dado a nosotros la vida, sino que nos la encontramos justamente al encontrarnos con nosotros. Un símil esclarecedor fuera el de alguien que dormido es llevado a los bastidores de un teatro y allí, de un empujón que lo despierta, es lanzado a las baterías, delante del público. Al hallarse allí, ¿qué es lo que halla ese personaje? Pues se halla sumido en una situación difícil sin saber cómo ni por qué. La situación difícil consiste en que hay que resolver de algún modo decoroso aquella exposición ante el público, que él no ha buscado ni preparado ni previsto» (VIII, 356). Como si se asomara a la metáfora inmensa del mundo como un teatro, pero no quisiera dar un paso más, como si hubiera algo ahí que no lo convenciera; como si viera más riesgos que ventajas en recorrer el mismo camino que otros (como hizo con Cervantes o Goethe), o incluso en presentar su propuesta existencial como una bifurcación audaz del tópico del theatrum mundi, con un reordenamiento de los elementos de la analogía, con un mejor análisis del teatro y del actor, para reinterpretarla desde su nueva comprensión de la vida, para recuperarla para su noción del hombre como, precisamente, res dramática.

\section{LAS DISONANCIAS DEL TEATRO COMO MUNDO}

De Calderón, Ortega escribe poco; ${ }^{38}$ de El gran teatro del mundo nada, ni de sus precedentes, los textos de Platón, Epicteto, Quevedo, y otros, en esa tradición literaria y filosófica larguísima, de miles de años, con la que su metafísica, si no converge, llega al menos a rozarse al recuperar la arquitectura dramática de la existencia. El final de «Idea del teatro» es apresurado, como otros muchos trabajos suyos, como si se encontrara de pronto con los folios pedidos ya escritos, con la extensión cumplida, y se viera obligado a cortar ahí, repentinamente, sin tiempo o sin ganas de reestructurar el artículo, sin aligerar el comienzo, retórico y remolón, independiente del tema, para ganar espacio al final, y dejar el texto o la ponencia más redondo. En sus conferencias de 1946 lleva el teatro a terreno metafísico, como ha hecho también con la novela o la

38 Solo unas pocas apreciaciones en Introducción a Velázquez sobre su técnica en la composición teatral: destaca los mecanismos efectistas de sus dramas, la búsqueda del enredo, la «manipulación prestidigitadora» en busca del aplauso. No le atribuye, en ningún caso, una proto-ontología, un primer paso en el desarrollo filosófico de la vida como drama. Solo algunos aciertos: «El hombre desde que nace está muriendo, como dijo Calderón» (VI, 807), o en La razón histórica de 1944: «Tenía razón Calderón en un sentido aún más concreto y trivial de lo que él supuso: por lo pronto, la vida es sueño, porque es sueño toda realidad que no se captura a sí misma, que no toma plena posesión de sí misma, que se queda dentro de sí y no logra, a la vez, evadirse de sí misma y estar sobre sí» (IX, 683). 
pintura antes: porque entiende que la farsa es constitutiva del hombre. Pero, para cerrar su exposición, deja fuera de la breve explicación que cuela sobre la vida, trascrita literalmente de ¿Qué es filosofía?, la imagen del actor que le había servido entonces de símil. En otros trabajos ha llamado al hombre res dramática, incluso actor, o se ha referido al «terrible escenario» de la vida (IX, 299). Pero para su reflexión específica del teatro decide cortar ahí, dejando esa función de evasión como la única continuación que propone para la irrealidad que es el teatro en tanto que arte, limitada la metáfora que es el actor a lo propiamente estético, sin conexión con la existencial metáfora que es, para él, el hombre. Un muñón que no explica. $\mathrm{O}$ bien porque quisiera cuidarse mucho de las metáforas, a esas alturas, con la lección aprendida después de la publicación de Ser y tiempo, para que no se entendiera la cuestión central de su filosofía como solo una metáfora, con una presentación demasiado literaria. ${ }^{39} \mathrm{O}$ bien porque entendiera que pudiera ser algo confuso para el auditorio referirse al actor primero directamente y luego como metáfora; o, en esa última embestida metafísica, como elemento para la evasión y, al tiempo, metáfora del hombre, sin apenas oportunidades de evadirse en la tarea que es su vida. O bien, la más significativa, la que sería más relevante. Porque viera que fallaba alguna pieza de la analogía. Porque pensara que su interpretación de la vida como tarea, con la voluntad del actor de constituirse en el personaje que perfila su vocación, era mejor mantenerla alejada de otras posibles representaciones metafóricas con el teatro como fondo, como marco; porque algunos de sus elementos podrían entenderse mal, difíciles de casar en una explicación global, en una alegoría con demasiadas piezas heredadas, innecesarias para el referente metafísico que le interesa a Ortega, en torno a la vocación como guía para construir una vida que no es dada hecha al individuo, que no tiene horma.

Epicteto en el Enquiridión escribe aquello de «Acuérdate de que eres actor de un drama que habrá de ser cual el autor lo quiera». La referencia que luego Quevedo (antes que Calderón) glosa, como si fuera el resumen del auto sacramental:

\footnotetext{
No olvides que es comedia nuestra vida y teatro de farsa el mundo todo que muda el aparato por instantes y que todos en él somos farsantes; acuérdate que Dios, de esta comedia de argumento tan grande y tan difuso, es autor que la hizo y la compuso. $\mathrm{Al}$ que dio papel breve,
}

39 Cf. J. Ortega y Gasset, «Pidiendo un Goethe desde dentro» (V, 127-128 n). 
solo le tocó hacerle como debe;

y al que se le dio largo,

solo el hacerle bien dejó a su cargo.

Si te mandó que hicieses

la persona de un pobre o un esclavo,

de un rey o de un tullido,

haz el papel que Dios te ha repartido;

pues solo está a tu cuenta

hacer con perfección el personaje,

en obras, en acciones, en lenguaje;

que al repartir los dichos y papeles,

la representación o mucha o poca

solo al autor de la comedia toca. ${ }^{40}$

Con esa analogía de la vida como comedia que es el marco general, con esa estructura dramática para la comprensión de la existencia, no lejos de Ortega; pero que es también la justificación de una moral de resignación, de sacrificio, de obediencia a Dios, sin apenas margen de maniobra, sin la libertad que Ortega le presupone al hombre para representar al personaje que es su auténtico yo (V, 125-126). Porque, en la alegoría completa del mundo como un teatro, Dios es el autor; y cada uno de los hombres, a un tiempo, actor y personaje, con una vida ya escrita, ya decidida, porque solo les queda ceñirse a la condición social asignada, con los márgenes muy estrechos. Moralmente bueno en tanto que se ajuste lo más posible, como actor, al personaje asignado; como personaje, sin ninguna autonomía; como actor, con los embrollos del libre albedrío, sin más libertad que elegir hacer bien o mal el papel ya escrito («Solo le tocó hacerle como debe», «Solo el hacerle bien dejó a su cargo»), obedecer mejor o peor, pero no reescribirlo, sin ni siquiera ese margen de indecisión que decía Ortega en «Elogio del "Murciélago"» que deja la obra al actor (II, 445).

Es representación la humana vida, escribe Calderón, con dos puertas: la cuna y el sepulcro. Con los papeles ya repartidos para este teatro, dice, de las ficciones, sin importar el de cada uno, porque es la capacidad de adecuación del actor al personaje, su voluntad de encorsetarse en el papel dado, ya escrito, lo que va a decidir su éxito o su fracaso, después del sepulcro, en el teatro de las verdades. Avisa el autor:

En la representación, igualmente satisface

40 Quevedo, Epicteto y Phocílides en español con consonantes, con el Origen de los estoicos, y su defensa contra Plutarco, y la Defensa de Epicuro, contra la común opinión. 


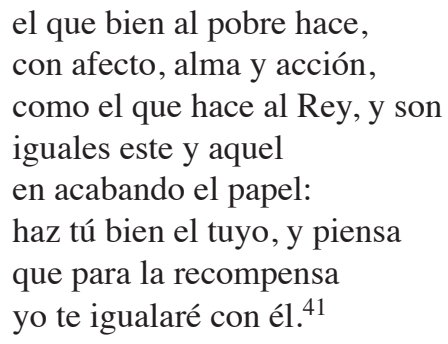

Con esa petición de cumplir bien el papel asignado, el que le han dado a uno, incluso arbitrariamente. Tan lejos de la propuesta de escribirse uno un buen papel de Ortega, más atento a la creación del personaje que a la actuación, aunque autor y actor sean el mismo, con este novelista o dramaturgo o actor que se escribe para sí el personaje que quiere interpretar, al tiempo que lo interpreta. Es la creación del papel, no su representación, aunque sea una misma acción, lo que le sirve de analogía a Ortega para su metafísica, en el otro extremo de cualquier determinismo, y de cualquier estructura fija para el ser. Y ahí, con la metáfora del novelista de sí mismo, a la que recurre más, puede ahorrarse -al crear un personaje que no tiene que ser encarnado- la confusión de este desdoblamiento: los dos tiempos o, al menos, las dos acciones (aunque sean simultáneas) en el desarrollo del personaje teatral, al crearlo como dramaturgo y al representarlo como actor, necesario para darle una coherencia interna a la analogía del teatro, pero un estorbo para la comprensión de su metafísica. De hecho, el actor de Calderón (o de Quevedo o de Epicteto) es para Ortega sólo un tipo concreto de hombre: el incapacitado para escribir su propio papel, que tiene que tomarlo de otro, estafándose a sí mismo, con una falsa trayectoria vital (VI, 486-487). Escribe en «El hombre y la gente», para su conferencia en Rotterdam: «La mayor parte de los hombres carece de fuerte fantasía creadora y es incapaz de crearse un programa original de vida, es decir, que ellos no se consagran a hacer y sin ayudas externas, no sabrían qué hacer; necesita recibir de fuera la figura de sí mismo que debe ejecutar en su existencia, el programa de sus actos, como el actor representa el papel que le ha encargado el dramaturgo. Pero, entiéndase bien esto, una cosa es que tal hombre sea incapaz de crearse su proyecto vital, su plan de vida, y otra que no tenga que decidirlo él. Esto es ineludible» (IX, 208).

41 P. Calderón de la Barca, El gran teatro del mundo. Madrid: Alianza, 1981, p. 143, vv. 409-418. 


\section{El PERSONAJE PROGRAMÁtico DE ORTEGA}

Quedan sin enlazar dos propuestas tremendamente sugerentes de Ortega. Desde su estética, con el actor como metáfora corporizada, que él propone, dotándolo de una capacidad creativa que no está en el actor dócil de la tradición literaria y filosófica. Hasta empalmar con su metafísica, con el hombre como existencial metáfora, como el personaje que no llega a realizarse nunca del todo (V, 540-541). Como una alternativa más exacta, más cargada de significado que sus dii consentes, para explicar la intervención conjunta del sujeto y su circunstancia para la constitución de la vida, en su superación del idealismo. El actor -había explicado ya antes- es, con el don de la transparencia, la universal metáfora corporizada (IX, 838). Una realidad ambivalente, dos realidades, la del actor y la del personaje, que se niegan mutuamente, dos yos que se contradicen, como ha dicho también Brecht. ${ }^{42}$ Escribe en «Idea del teatro»: «La realidad de una actriz, en cuanto que es actriz, consiste en negar su propia realidad y sustituirla por el personaje que representa. Esto es re-presentar: que la presencia del actor sirva no para presentarse a sí mismo, sino para presentar otro ser distinto de él» (IX, 837). Que quede solo lo irreal, lo imaginario, tras haberse neutralizado ambas realidades, cuando el actor ha dejado de ser el hombre real que es y, al tiempo, el personaje se desprende de lo que fue antes de su representación. Con el mecanismo de la metáfora; con las dos realidades enfrentadas, en un mismo lugar, para crear con la transferencia mutua una realidad nueva; con esa primera identidad inesencial que sirve solo de toma de contacto, para dar no con lo común a ambas sino con un nuevo elemento, como si al romperse los caparazones de los dos términos al chocar entre sí -escribela materia interna, blanda, maleable, recibiera una nueva forma y estructura (I, 673-677). Que en el ámbito de la metafísica, trasladada la estructura, podrían ser el yo y su circunstancia, como con los dioses consentes, esa pareja de dioses que nacían y morían juntos, o la vocación (como la llamada íntima del hombre a realizarse $)^{43}$ y la circunstancia, enfrentadas en el propio movimiento interno que exige esta metáfora del actor, en el choque de ambas, que revela -por el significado, pero también por su propia articulación- el carácter ejecutivo de la vida, ese dinamismo, que es también creación, que hace innecesario el rol del autor (exógeno): el elemento de fricción entre la analogía de Ortega y la del theatrum mundi. Escribe en 1932, en «A una edición de sus obras»: «Hay que hacer nuestro quehacer. El perfil de este surge al enfrentar la vocación de cada cual con la circunstancia. Nuestra vocación oprime la circunstancia, como

42 B. Brecht, Escritos sobre teatro. Barcelona: Alba, 2004, p. 267.

43 Escribe en «El hombre a la defensiva» de 1929: «No hay vida sin vocación, sin llamada íntima. La vocación procede del resorte vital, y de ella nace, a su vez, aquel proyecto de sí misma, que en todo instante es nuestra vida» (II, 748). 
ensayando realizarse en esta. Pero esta responde poniendo las condiciones a la vocación» $(\mathrm{V}, 96)$. Con ese mismo movimiento doble de la metáfora en que se enfrentan uno y otro; esa existencial metáfora de la que escribe en «Máscaras», un anexo que se añade mucho más tarde a «Idea del teatro». ${ }^{44}$

En «Elogio del "Murciélago"», en un plano estrictamente estético, Ortega ya había arremetido contra el actor dócil que parece que exige el teatro tradicional o clásico, que le da al dramaturgo plenos poderes. Escribe entonces el diagnóstico: «Una vez que el autor pone lo que en su personaje hay de singular e interesante, solo queda a cargo del actor lo que hay de genérico e insignificante en la figura». Y la solución: «Es preciso, ante todo, que el actor deje de ser lo que es hoy, mero realizador de una obra escrita, y se convierta en otra cosa; mejor dicho, en mil cosas: acróbata, danzarín, mimo, juglar, haciendo de su cuerpo elástico una metáfora universal» (II, 448). Una reasignación de tareas que mantiene para el plano metafísico, para su definición del hombre, que arraiga en el compromiso o en la obligación de construirse cada uno un personaje, como hace el actor. La clave se la da Goethe. Lo llama el ser bifronte, porque descubre su yo auténtico, pero se mantiene infiel a su destino $(\mathrm{V}, 126)$. Confunde todavía el yo que cada uno tiene que ser con el yo normativo, pero da los primeros pasos para sustituir el imperativo de la ética abstracta por lo íntimo, lo concreto, lo vital: entrevé que la vida es por sí misma ética. Lo que Jaime de Salas ha llamado una ética de la perspectiva, ${ }^{45}$ por la fidelidad del individuo a ese destino propio. Que impregna, con su sentido moral, la comprensión de Ortega de la vida como biografía, como el proyecto del hombre que, sin una identidad constitutiva, sin un ser determinado, tiene que inventarse una figura de vida, el personaje que va a ser, que ha resuelto ser (VI, 66-72). La máxima de Píndaro, bien exprimida: «Sé el que eres». Como ha escrito José Lasaga, es un vacío que irremediablemente ha de ser llenado: la propia vida es una operación radicalmente creadora. ${ }^{46}$

Pero Ortega no quiso llevar más allá la analogía del actor en el teatro. Quizá por los referentes que debía asignarles al actor y al personaje, con esa misma relación de enfrentamiento, de querer anularse uno al otro, que tienen como elementos de la metáfora. ${ }^{47}$ Quizá pensó que no era necesario llevar hasta ahí su comprensión de la vida, que el riesgo de confundir algunos puntos de su

44 Escribe Ortega: «El hombre se pasa la vida queriendo ser otro. Pero el texto de la conferencia nos ha hecho ver que la única manera posible de que una cosa sea otra es la metáfora -el "ser como" o cuasi-ser. Lo cual nos revela inesperadamente que el hombre tiene un destino metafórico, que el hombre es la existencial metáfora.» (IX, 871).

45 Cf. J. de Salas, «Ortega y la ética de la perspectiva», Revista de estudios orteguianos 6 (2003) p. 89.

46 J. Lasaga Medina, Figuras de la vida buena. op. cit., p. 196.

47 Vocación y circunstancia propiamente no se anulan en su enfrentamiento. 
propuesta original era muy alto, y prefirió andarse con cuidado, aunque pudiera tentarle la posibilidad de adecuar a su filosofía la imagen del theatrum mundi, una vez remozada con esa herramienta que deja dispuesta en su estética: la metáfora corporizada, como otro elemento distinto al actor y al personaje, frente a la confusión clásica. Como si no necesitara esos arneses con la metáfora (esa potencial metáfora rehecha por él), porque no le sale a cuenta el impacto visual de la explicación a cambio de esa deuda, luego, cada vez que escriba su metafísica, obligado a atender los paralelismos, contradicciones e inexactitudes no de su propuesta, lo propiamente filosófico, sino del careo de esta con la analogía del actor. No se plantea jugarse toda su metafísica a una sola carta, a una sola imagen, aunque sea tan sugerente.

EnRIQUe FerRari Nieto es investigador doctor en la Universidad de Extremadura.

Líneas de investigación:

Ortega y Gasset, filosofía española del siglo XX, filosofía de la literatura y estética.

Publicaciones recientes:

(2010) Diccionario del pensamiento estético de Ortega y Gasset, Zaragoza: Mira Editores.

(2012) «Limitaciones de la metáfora de la inmersión en la comprensión de novela e Internet como espacios virtuales análogos». Revista de Filosofía (ISSN: 0034-8244), vol. 36, nº 2.

Dirección electrónica: eferrari@unex.es 
